\title{
Teaching Professionalization of the Doctor Guarantee for Sustainable Development
}

\author{
Claribel Plain Pazos ${ }^{1 *}$, Carmen Rosa Carmona Pentón ${ }^{1}$, Elsa Núñez Escobar ${ }^{2}$, Anisbel Pérez de \\ Alejo Plain ${ }^{3}$, René Vázquez Estévez ${ }^{4}$, Roberto N Aguiar Delgado ${ }^{5}$ and Yilian Burgos Santos ${ }^{6}$
}

${ }^{1}$ Assistant Professor, Faculty of Medical Sciences of Sagua la Grande, Villa Clara, Cuba

${ }^{2}$ Assistant Professor, Faculty of Medical Sciences of Sagua la Grande, Villa Clara, Cuba

${ }^{3}$ Medical Faculty of Medical Sciences of Sagua la Grande, Villa Clara, Cuba

${ }^{4}$ Assistant Professor, Teaching General Teaching Hospital Sagua la Grande, Villa Clara, Cuba

${ }^{5}$ Professor, Teaching General Teaching Hospital, Sagua la Grande, Villa Clara, Cuba

${ }^{6}$ Assistant Professor, Teaching General Teaching Hospital "Sagua la Grande, Villa Clara, Cuba

*Corresponding author: Claribel Plain Pazos, Specialist of II Degree in Comprehensive General Medicine, Assistant Professor,

Faculty of Medical Sciences of Sagua la Grande, Villa Clara, Cuba

\begin{tabular}{|c|c|}
\hline ARTICLE INFO & ABSTRACT \\
\hline Received: April 13, 2020 & Citation: Claribel Plain P, Carmen Rosa Carmona P, Elsa Núñez E, Anisbel Pérez de \\
\hline Published: 豐 April 24, 2020 & $\begin{array}{l}\text { Alejo P, René Vázquez E, et al. Teaching Professionalization of the Doctor Guarantee for } \\
\text { Sustainable Development. Biomed J Sci \& Tech Res 27(2)-2020. BJSTR. MS.ID.004472. }\end{array}$ \\
\hline
\end{tabular}

\section{Short Communication}

Man has no perception of risk and is destroying his own habitat! The human race is in danger of disappearing! It is well known that in recent years due to the action of man there have been notable changes in climatic conditions that have impacted on human health. Extreme air temperatures contribute to deaths from cardiovascular and respiratory diseases, especially among the elderly [1-3]. Climate changes are likely to prolong the transmission stations of important vector-borne diseases and alter their geographical distribution, for example diseases such as schistosomiasis, malaria and dengue fever can increase and expand the epidemic map [1]. Between 2030 and 2050 , climate change is expected to cause an additional 250,000 deaths each year due to malnutrition, malaria, diarrhea and caloric stress [4]. Meeting the objectives of the Paris Agreement could save around one million lives annually by 2050 , only considering the goal of reducing air pollution [2,4].Since 1959, it has been the will of the Cuban government to improve the health of the population based on a strategy of the Ministry of Public Health in Cuba whose purpose would be to optimize and increase the efficiency and preventive-care quality in health services, to ensure sustainability of the system despite economic constraints [5].
The formulation of climate change adaptation measures must include all sectors of society. In Cuba the state has created mechanisms to prepare the population, adopting measures that involve the country's educational centres. An example of this is the life task, which is a Cuban State Plan for confronting climate change. The plan contains 5 actions and 11 tasks aimed at counteracting the effects of climate change in vulnerable areas. Task 10 contains prioritizing measures and actions to raise the perception of risk and increase the level of knowledge and the degree of participation of the entire population in confronting climate change and a culture that encourages water savings [6]. Medical schools are no stranger to this Plan. It is the responsibility of the medical teacher to train future doctors in these concepts by turning them into health promoters with knowledge and skills to educate the population and contribute to the reduction of the impact of climate change on health. Thus, guaranteeing the guidelines for sustainable development.

In the lecture given by Dr. Guillermo Mena Ridel, professor of the National School of Health, during the II Symposium on Climate Change and Health that was part of the scientific program of the $\mathrm{X}$ Cuban Congress of Meteorology, whose work sessions ended on 
Friday 6 of December 2019 at the Tryp Habana Libre Hotel, in the Cuban capital, one of the edges of the State Plan for confronting Climate Change (Task Life) was highlighted, which is based on raising the perception of risk and increasing knowledge and the participation of the population in the adaptation to climate change, fostering a culture for saving water and energy resources [7].

The doctor who needs today's society must not only diagnose and treat diseases but must also prevent them. But to properly train these future doctors, it is necessary to have a competent Cloister, who has knowledge of the profession, but also pedagogical preparation, which provides the necessary tools so that he can transmit knowledge while forming skills and values necessary for the output profile of the medical staff you are training. Assuming that the doctor, because of his quality as such, is qualified to teach, and therefore, that his students learn, is part of the past. The challenge is to go further; It is imperative to have the implementation of properly structured programs, based on the need's assessment within each school and with a study of its impact [8]. To be a professor of a medical school, it is not enough to be a good health professional, but you must achieve the skills for teacher professionalization. Hence, it is appropriate to reflect on how the medicine professor is and should be the role of other doctors and what strategies the responsible and adequately pedagogical exercise of their work in the classroom and in the practice, scenarios present [9].

Regarding climate change and its consequences, the teacher's work is focused on preparing future doctors in the adaptation and

ISSN: 2574-1241

DOI: $10.26717 /$ BJSTR.2020.27.004472 Adel Bouguezzi. Biomed J Sci \& Tech Res

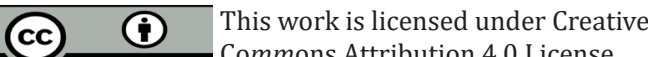

Submission Link: https://biomedres.us/submit-manuscript.php positive transformation of the environment, as well as providing them with the necessary tools to educate the population in taking action under mitigate the negative effects that climate change generates on health. Communicable diseases such as dengue, malaria, schistosomiasis, which currently threaten the world, can be preventable if appropriate health measures are used by health authorities in joint work with the entire population. To ensure sustainable development, everyone's joint work is needed, but with a common objective and intentionality.

\section{References}

1. (2018) OMS. Cambio climático y salud. Word Health Organization.

2. (2018) ONU. Luchar contra el cambio climático beneficia la salud y el bolsillo.

3. (2018) CNN en Español. El cambio clim tico tiene más efectos para tu salud de los que piensas.

4. (2018) OPS/OMS. Advierten sobre las consecuencias del cambio climático en la salud, Buenos Aires.

5. (2017) Dickinson Meneses FO, Retos del cambio climático para la salud Pública en Cuba. rev Cubana Hig Epidemiol 55(2): 1-3.

6. (2017) CITMA. Tarea Vida, Ecured: Enciclopedia cubana.

7. Peláez O (2019) Proteger la salud humana del cambio climático.

8. Osornio Castillo L, Sánchez Reyes C, Ríos Saldaña MR, Méndez Cruz AR, Moreno Fernández AA, et al. (2015) Autoevaluación de los profesores de clínica integral de medicina sobre su desempeño docente. RevInvest en EducMéd 4(16): 183-189.

9. Jara Gutierrez NP, Díaz López MM, Zapata Castañeda PN (2015) Desafíos educativos para el profesor de medicina: evaluación de su desempeño. IATREIA 2015 28(3): 292-299.

\begin{tabular}{ll} 
BIOMEDICAL & Assets of Publishing with us \\
RESEARCHES & - Global archiving of articles \\
& - Immediate, unrestricted online access \\
\hline
\end{tabular}

